\title{
Induction of apoptosis by in vitro and in vivo plant extracts derived from Menyanthes trifoliata $\mathbf{L}$. in human cancer cells
}

\author{
Tomasz Kowalczyk (ib) Przemysław Sitarek • Ewa Skała • Monika Toma • \\ Marzena Wielanek · Dariusz Pytel · Joanna Wieczfińska · Janusz Szemraj • \\ Tomasz Śliwiński
}

Received: 27 February 2018/Accepted: 25 October 2018/Published online: 4 January 2019

(C) The Author(s) 2019

\begin{abstract}
Menyanthes trifoliata L. has been used in traditional medicine for centuries. It exists in Asia, Europe, North America and in Morocco and is exploited as a remedy for anemia and lack of appetite. This plant shows many pharmacological properties, but its most interesting one is its anti-cancer potential. The present study examines the induction of apoptosis in grade IV glioma cells after treatment with the extracts from aerial part and root of $M$. trifoliata plants derived from in vitro (MtAPV and MtRV, respectively) and from soil (MtAPS and MtRS, respectively) and presents the first comparison of the biological effects of four different extracts of $M$. trifoliata against glioblastoma cells. The root extracts of $M$. trifoliata
\end{abstract}

Tomasz Kowalczyk and Przemysław Sitarek have contributed equally to this work.

T. Kowalczyk $(\bowtie)$

Department of Genetics, Plant Molecular Biology and Biotechnology, Faculty of Biology and Environmental Protection, University of Lodz, Banacha 12/16, 90-237 Lodz, Poland

e-mail: tomasz.kowalczyk@biol.uni.lodz.pl

P. Sitarek · E. Skała

Department of Biology and Pharmaceutical Botany, Medical University of Lodz, Muszynskiego 1,

90-151 Lodz, Poland

M. Toma - T. Śliwiński

Laboratory of Medical Genetics, Faculty of Biology and Environmental Protection, University of Lodz, Pomorska 141/143, 90-236 Lodz, Poland plants were found to exhibit cytotoxic effects against grade IV glioma cells, but not normal human astrocytes. HPLC analysis demonstrated the presence of various polyphenolic compounds, including sinapinic acid, ferulic acid, syringic acid and vanilic acid. Higher amount of pentacyclic triterpene (betulinic acid) was also found in MtRV extract. The growth inhibition of human grade IV glioma cells mediated by MtRV extract appears to be associated with apoptosis and $\mathrm{G} 2 / \mathrm{M}$ phase cell cycle arrest, and altered expression of the pro- and anti-apoptotic genes ( $\mathrm{Bax}, \mathrm{Bcl}-2$, Cas-3 and TP53) and proteins (Bax, Bcl-2, Cas-3 and p53), as well as decreased mitochondrial membrane potential. Our results indicate that $M$. trifoliata gives promising results as an anti-cancer agent for human glioblastoma cell lines. However, further research is necessary in view of its therapeutic use.

M. Wielanek

Department of Plant Physiology and Biochemistry,

Faculty of Biology and Environmental Protection,

University of Lodz, Banacha 12/16, 90-237 Lodz, Poland

D. Pytel

Department of Biochemistry and Molecular Biology, Medical University of South Carolina, Hollings Cancer Center, HCC-709, 86 Jonathan Lucas Street, Charleston, SC 29425, USA 
Keywords Glioma cells - Menyanthes trifoliata . Apoptosis · Genes expression · Flow cytometry · HPLC analysis

\section{Introduction}

Despite the development of very precise diagnostic and therapeutic methods, gliomas remain one of the most challenging diseases of the central nervous system. It has high rates of recurrence and is one of the leading causes of death worldwide (Davis 2016). In Europe alone, 27,000 new cases of malignant astrocytic tumors are diagnosed every year (http:// www.rarecarenet.eu/rarecarenet/). However, existing therapies, such as surgical resection followed by adjuvant external beam radiation and chemotherapy, are being constantly improved. Currently, the most commonly-used chemotherapeutics for glioma are temozolomide (Wang et al. 2017), carmustine and PCV (procarbazine, vincristine, lomustine), but these also demonstrate significant toxicity towards healthy tissues. An alternative approach to traditional therapeutic methods is application of anti-cancer compounds derived from plants: there are many chemicals with antineoplastic properties in the plant kingdom and the list of plant species known to have anticancer properties is constantly growing. One of the most interesting groups of plant chemical compounds exhibiting anticancer properties are the phenolic acids including chlorogenic, ellagic, sinapinic, syringic and caffeic (Guimarães et al. 2007; Zhang et al. 2015a, b; Ahire et al. 2017; Deka et al. 2017; Mady and Shaker 2017; Sadeghi Ekbatan et al. 2018). Another biologically-active group of compounds with anticancer properties are the terpenoids. This is a large group of natural compounds derived from C30 precursors including triterpenes, steroids, limonoids, quassinoids,

\section{J. Wieczfińska}

Department of Immunopathology, Chair of Allergology, Immunology and Dermatology, Faculty of Biomedical Sciences and Postgraduate Training, Medical University of Lodz, 90-752, Żeligowskiego 7/9, Lodz, Poland

J. Szemraj

Department of Medical Biochemistry, Medical University of Lodz, Mazowiecka 6/8, 92-215 Lodz, Poland triterpenoidal and steroidal saponins (Sandjo and Kuete 2013). These compounds have considerable potential in the fight against different types of human cancer (Huang et al. 2012), with naturally-occuring terpenoids playing a role in the chemoprevention and therapy of cancer cells. Triterpenes appear to play an important role in this regard: actein, astragaloside IV, cucurbitacin I, ursolic acid and betulinic acid all exhibit cytotoxic properties against various types of tumors (Escandell et al. 2008; Einbond et al. 2009; Qi et al. 2010; Tiwari et al. 2014; Kim et al. 2015). The latter deserves special attention due to its wide antineoplastic effect. Betulinic acid (3b-hydroxy-lup20(29)-en-28-oic acid) is naturally-occuring pentacyclic lupane-type triterpenoid present in a range of plant species including Betula alba, Eucalyptus sp., Lavandula angustifolia, Platanus acerifolia, Rosmarinus officinalis (Tiwari et al. 2014) and Menyanthes trifoliata (Stabursvik 1953; Janeczko et al. 1990; Patočka 2003). M. trifoliata L. (Menyanthaceae) is found throughout the northern hemisphere. It is a marsh plant that grows about thirty centimeters high, and offers a range of pharmacological effects including anti-inflammatory or immunomodulating properties (Tunón et al. 1994; Huang et al. 1995; KudukJaworska et al. 2004) and is a rich source of betulinic acid and triterpene saponines (Patočka 2003).

This study is the first one to investigate the cytotoxic effect, the expression of apoptotic-related genes, and the induction of apoptosis in a human glioma cell line after treatment with extracts prepared from aerial parts and roots derived from in vitro (MtAPV and MtRV) and from soil-grown (MtAPS and MtRS) M. trifoliata plants. The main polyphenolic compounds in the tested extracts were identified and quantified by HPLC analysis.

\section{Materials and methods}

Establishment of in vitro and soil-grown $M$. trifoliata plants

Axenic in vitro culture was set up using $M$. trifoliata seeds. The seeds were surface sterilized as follows: The seeds were placed in $70 \%$ ethanol $(\mathrm{EtOH})$ for one minute. After this time, the EtOH was replaced with $30 \%$ commercial bleach ACE (Procter\&Gamble) and the tubes inverted from time to time for ten minutes. 
The bleach was then removed and the seeds washed five times for five minutes with sterile water.

The sterilized seeds were germinated under aseptic conditions on SH medium (Schenk and Hildebrandt 1972) supplemented with vitamins, $50 \mathrm{mg} \mathrm{L}^{-1}$ gibberellic acid $\left(\mathrm{GA}_{3}\right.$, Duchefa Biochemie, Haalen, The Netherlands) and $0.02 \mathrm{mg} \mathrm{L}^{-1}$ kinetin as described previously (Adamczyk-Rogozinska and Wysokińska 1998) (Fig. 1a). The medium was solidified with $0.8 \%$ agar. A sterile hood was used for preparing the culture.

After 10 weeks, the seedlings were transferred to liquid $\mathrm{SH}$ medium for culture under the following conditions: $16 / 8 \mathrm{~h}$ light/dark photoperiod, light intensity $40 \mu \mathrm{mol} \mathrm{m}{ }^{-2} \mathrm{~s}^{-1}$, temperature $26{ }^{\circ} \mathrm{C}$.

The resulting shoot tips were excised and placed on SH medium $\left(0.8 \%\right.$ agar, $0.5 \mathrm{mg} \mathrm{L}^{-1}$ indole-3-acetic acid (IAA, Duchefa Biochemie), $1 \mathrm{mg} \mathrm{L}^{-1}$ 6-benzylaminopurine (BAP, Duchefa Biochemie). After 30 days, the shoot tips were subcultured on solid SH medium with $0.5 \mathrm{mg} \mathrm{L}^{-1}$ BAP for shoot elongation. Following this, $1-2 \mathrm{~cm}$ shoots were placed on $\mathrm{SH}$ with $0.8 \%$ agar and $0.5 \mathrm{mg} \mathrm{L}^{-1}$ IAA (Duchefa Biochemie, Haalen, The Netherlands) for rooting for 6 weeks. The rooted shoots (Fig. 1c) were then moved to liquid SH medium for further growth. The in vitro plants were subcultured every 4 weeks on new liquid $\mathrm{SH}$ medium (Fig. 1f). Plant material in vitro propagation was followed by apical meristem.

The procedure for creating soil-grown plants was as follows: the seeds were planted in a sterile mixture of soil, peat and sand (3:1:1 v/v) (Adamczyk-Rogozinska and Wysokińska 1998) for germination in the greenhouse under the following conditions: temperature

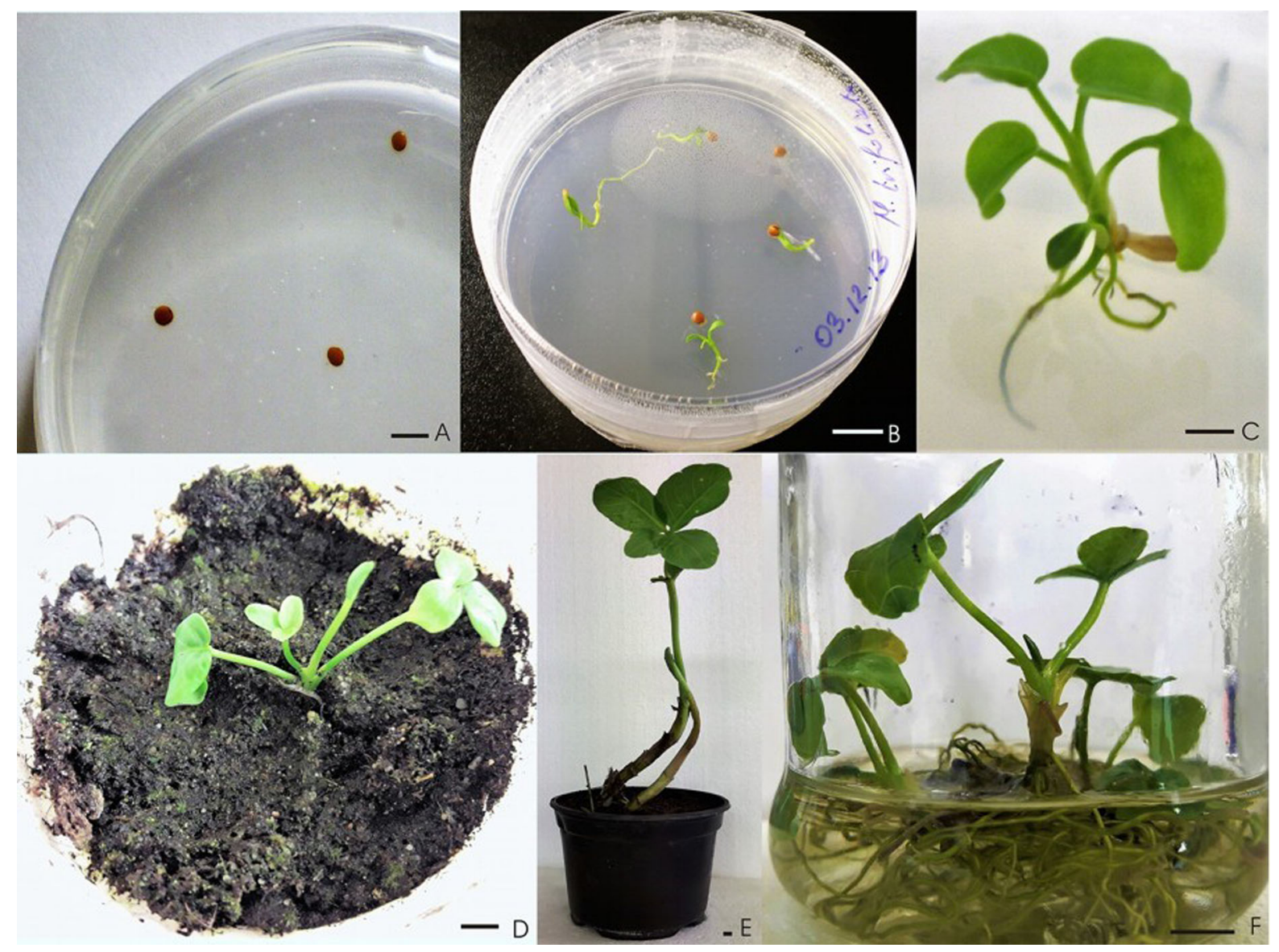

Fig. 1 Development stages of Menyanthes trifoliata in vitro and in vivo (soil-grown) conditions. a Seeds after surface sterilization. b Seeds germination after 1 month, c 6 weeks old in vitro plant, d 3 month old plant in soil, e $M$. trifoliata after 1 year, $\mathbf{f}$ plants in vitro cultured in liquid $\mathrm{SH}$ medium $($ bar $=1 \mathrm{~cm})$ 
$26{ }^{\circ} \mathrm{C}, 16 / 8 \mathrm{~h}$ light/dark photoperiod, light intensity of $40 \mu \mathrm{mol} \mathrm{m}{ }^{-2} \mathrm{~s}^{-1}$.

A voucher specimen was deposited at the Department of Genetics, Plant Molecular Biology and Biotechnology, University of Lodz, Poland.

Plant extract preparation

Four different $M$. trifoliata extracts were used: two from 1-year-old in vitro derived plants (Fig. 1e, f) obtained from the aerial parts (MtAPV) and roots (MtRV) (Fig. 2), and two from plants obtained from soil grown for 1 year in the greenhouse from the aerial parts (MtAPS) and roots (MtRS). Briefly, the extracts were prepared as described previously (Sitarek et al. 2016b). The yields (w/w) of the extracts with regard to initial dry weight of plant material were $52.8 \%$ and $50.4 \%$ for MtAPV and MtRV for in vitro plants, respectively, and $54.2 \%$ and $48.4 \%$ for MtAPS and MtRS for soil-grown plants, respectively.

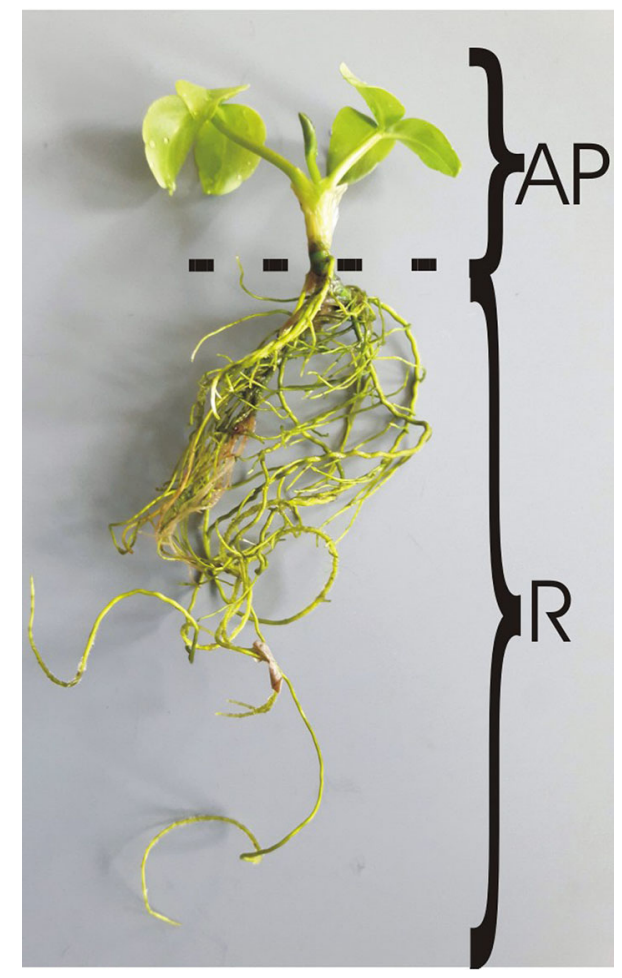

Fig. 2 Aerial parts and roots of in vitro M. trifoliata (AP aerial parts, $\mathrm{R}$ roots)
Phytochemical analysis

The phenolic compounds were examined by HPLC method (Dionex, Sunnyvale, CA, USA) (Sitarek et al. 2016a). The results are presented in Table 1. Identification and quantification of betulinic acid were conducted according to the modified method of Pai et al. (2011). Chromatographic analysis was carried out using HPLC system (Dionex) equipped with a photodiode-array detector. Chromatographic separation was achieved on a Supelcosil RP column (C18, $4.0 \mathrm{~mm} \times 150 \mathrm{~mm}, 5 \mu \mathrm{m})$. joined with a guard column (GOLD Drop-In guards, $10 \times 4 \mathrm{~mm}, 5 \mu \mathrm{m}$, Polygen, Gliwice, Poland) at $25{ }^{\circ} \mathrm{C}$. Mobile phase consisting of $16 \%$ water (A) and $84 \%$ acetonitrile (B) in an isocratic mode with injection volume $20 \mu \mathrm{l}$. The flow rate was $1 \mathrm{~cm}^{3} \mathrm{~min}^{-1}$ and the absorbance was measured at $210 \mathrm{~nm}$, the analysis time was 12 min for both standards and plant extracts. Betulinic acid in plant extracts were identified by comparing the retention time and UV spectra of the analyzed samples with the respective data obtained from the analysis of reference standard. Quantification was based on the calibration curve for betulinic acid standard constructed over the range of $5-250 \mu \mathrm{g} \mathrm{cm}^{-3}$, the linearity of the calibration curve was verified by the correlation coefficient $\left(r^{2}=0.9982\right)$.

\section{Cell culture}

In this study two cell lines were used. Normal human astrocytes (NHA) (Lonza, Basel, Swizerland, CC2565) were grown in AGM (Lonza, Basel, Swizerland, CC-3187) medium supplemented according to the manufacturer's protocol, while grade IV glioma cells were derived from a tumor patient. Briefly, cells were cultured with DMEM medium (ThermoFisher Scientific, CA, USA, Gibco, 31331-028) supplemented with 10\% FBS (EuroClone, Pero, MI, Italy) 100 Units/mL penicillin and $100 \mu \mathrm{g} / \mathrm{mL}$ streptomycin under a humidified atmosphere with $5 \% \mathrm{CO}_{2}$ and $95 \%$ air at $37{ }^{\circ} \mathrm{C}$. In all experiments, $4 \times 10^{5}$ cells were seeded per $75 \mathrm{~cm}^{2}$ flask. The confirmation of carcinogenic nature of these cells and further procedures are given in a previous study (Sitarek et al. 2016a). 
Table 1 The contents of secondary metabolites in Menyanthes trifoliata plants obtained in vitro and in vivo cultures

\begin{tabular}{|c|c|c|c|c|c|}
\hline No. & Compounds & $\begin{array}{l}\text { MtRV } \\
\mu \mathrm{g} \mathrm{g}^{-1} \text { dry weight }\end{array}$ & MtAPV & MtRS & MtAPS \\
\hline 1 & Betulinic acid & $5437.15 \pm 141.33^{c}$ & $395.31 \pm 14.5^{\mathrm{a}}$ & $3938.95 \pm 82.65^{b}$ & $390.00 \pm 15.87^{a}$ \\
\hline 2 & Vanillic acid & $2.83 \pm 0.16^{\mathbf{c}}$ & $2.23 \pm 0.09^{\mathbf{b}}$ & $1.98 \pm 0.09^{\mathrm{b}}$ & $1.43 \pm 0.06^{\mathrm{a}}$ \\
\hline 3 & Syringic acid & $113.80 \pm 0.80^{c}$ & n.d. & $29.96 \pm 0.05^{b}$ & $0.98 \pm 0.02^{\mathrm{a}}$ \\
\hline 4 & Ferulic acid & $13.80 \pm 0.80^{\mathbf{b}}$ & n.d. & $5.09 \pm 0.14^{\mathrm{a}}$ & n.d. \\
\hline 5 & Sinapinic acid & $146.53 \pm 7.03^{d}$ & $71.16 \pm 3.34^{\mathrm{b}}$ & $86.12 \pm 5.81^{c}$ & $45.84 \pm 1.60^{\mathrm{a}}$ \\
\hline 6 & $o$-coumaric acid & $3.42 \pm 0.11^{\mathrm{c}}$ & $2.95 \pm 0.13^{\mathrm{c}}$ & $2.07 \pm 0.09^{\mathrm{b}}$ & $1.18 \pm 0.03^{\mathrm{a}}$ \\
\hline 7 & Salicylic acid & $8.68 \pm 0.47^{\mathrm{d}}$ & $4.21 \pm 0.26^{\mathrm{b}}$ & $5.10 \pm 0.27^{\mathrm{c}}$ & $2.71 \pm 0.12^{\mathrm{a}}$ \\
\hline 8 & Ellagic acid & $518.11 \pm 26.46^{c}$ & $450.65 \pm 14.22^{b}$ & $326.98 \pm 20.92^{a}$ & $298.64 \pm 12.54^{a}$ \\
\hline 9 & Coumarin & $17.69 \pm 0.51^{\mathrm{d}}$ & $11.37 \pm 0.62^{\mathrm{c}}$ & $5.45 \pm 0.30^{\mathrm{a}}$ & $7.01 \pm 37.2^{\mathrm{b}}$ \\
\hline 10 & t-3-hydroxycinnaminic acid & $4.77 \pm 0.25^{\mathrm{d}}$ & $2.03 \pm 0.08^{c}$ & $0.27 \pm 0.008^{\mathrm{a}}$ & $1.43 \pm 0.05^{\mathrm{b}}$ \\
\hline 11 & Hesperidin & $60.73 \pm 3.27^{\mathrm{c}}$ & $70.50 \pm 3.80^{\mathrm{d}}$ & $39.17 \pm 3.40^{\mathrm{a}}$ & $47.59 \pm 2.28^{\mathrm{b}}$ \\
\hline 12 & t-cinnaminic acid & $3.98 \pm 0.21^{\mathrm{c}}$ & $3.11 \pm 0.12^{\mathrm{b}}$ & $2.87 \pm 0.07^{\mathrm{b}}$ & $1.89 \pm 0.06^{\mathrm{a}}$ \\
\hline 13 & Hesperetin & $43.04 \pm 1.54^{\mathrm{c}}$ & $20.19 \pm 0.78^{b}$ & $20.94 \pm 0.85^{\mathrm{b}}$ & $11.96 \pm 0.56^{\mathrm{a}}$ \\
\hline 14 & Neochlorogenic acid & $11.62 \pm 0.66^{\mathrm{c}}$ & $11.87 \pm 0.52^{\mathrm{c}}$ & $5.70 \pm 0.19^{\mathrm{a}}$ & $7.73 \pm 0.40^{\mathrm{b}}$ \\
\hline 15 & Gentisinic acid & $11.65 \pm 0.33^{\mathrm{b}}$ & $35.72 \pm 1.28^{\mathrm{d}}$ & $7.64 \pm 0.34^{\mathrm{a}}$ & $25.46 \pm 1.19^{c}$ \\
\hline 16 & Chlorogenic acid & $177.34 \pm 9.57^{b}$ & $257.9 \pm 14.70^{c}$ & $128.77 \pm 7.21^{\mathrm{a}}$ & $178.13 \pm 7.83^{b}$ \\
\hline 17 & Caffeic acid & $1.16 \pm 0.03^{\mathrm{c}}$ & $1.31 \pm 0.02^{\mathrm{c}}$ & $0.65 \pm 0.28^{\mathrm{a}}$ & $0.84 \pm 0.02^{\mathrm{b}}$ \\
\hline 18 & 1,3-dicaffeoylquinic acid & $0.89 \pm 0.02^{\mathrm{d}}$ & $0.22 \pm 0.0072^{\mathrm{b}}$ & $0.35 \pm 0.0042^{\mathrm{c}}$ & $0.15 \pm 0.0075^{\mathrm{a}}$ \\
\hline 19 & $p$-Coumaric acid & $10.74 \pm 0.44^{\mathrm{b}}$ & $15.78 \pm 0.42^{\mathrm{c}}$ & $6.89 \pm 0.15^{\mathrm{a}}$ & $9.66 \pm 0.41^{\mathrm{b}}$ \\
\hline 20 & Luteolin & $9.08 \pm 0.28^{\mathrm{d}}$ & $7.16 \pm 0.27^{\mathrm{c}}$ & $5.74 \pm 0.29^{\mathrm{b}}$ & $1.68 \pm 0.06^{\mathrm{a}}$ \\
\hline 21 & Rutin & $256.20 \pm 3.24^{d}$ & $152.99 \pm 6.42^{b}$ & $180.04 \pm 2.86^{c}$ & $82.34 \pm 3.04^{\mathrm{a}}$ \\
\hline \multicolumn{2}{|c|}{ Sum of phenolic compounds } & 1416,06 & 1121,35 & 861,78 & 726,65 \\
\hline
\end{tabular}

The compounds were determined in $80 \%$ aqueous methanol extracts from roots and aerial parts of plants obtained from in vitro (MtRV and MtAPV) and in vivo (MtRS and MtAPS) cultures. Different superscript letter within the rows indicate significant differences in the mean values at $p<0.05$. The compounds present in the highest concentrations are given in bold

Cytotoxicity of extracts from in vitro and soilgrown M. trifoliata plants

Cytotoxicity of plant extracts was evaluated by MTT assay [3-(4,5-dimethylthiazol-2-yl)-2,5-diphenyltetrazolium bromide] (Thermo Fisher Scientific), which assesses cell metabolic activity according to the manufacturer's instructions. Cells $(1 \times 104$ cells $)$ were plated in 96-well plates in $100 \mu \mathrm{L}$ culture medium containing various concentrations (range 0-4 mg mL ${ }^{-1}$ ) of plant extracts (MtRV, MtRS, MtAPV or MtAPS). $20 \mu \mathrm{L}$ of MTT solution ( $5 \mathrm{mg} \mathrm{mL}^{-1}$ MTT in PBS) was then added to each well and the plate was incubated in $37^{\circ} \mathrm{C}$ until formazan crystals were visible. Then, medium was discarded from wells and the crystals were dissolved in $100 \mu \mathrm{L}$ of DMSO (Sigma-Aldrich, St. Louis, MO,
USA). After $15 \mathrm{~min}$ incubation at room temperature plates were read in a microplate spectrophotometer (OMEGA) at $550 \mathrm{~nm}$.

RNA isolation and quantitative RT-PCR

Briefly, the cells were plated into 6-well culture dishes $\left(3 \times 10^{5}\right.$ cells/well) for $24 \mathrm{~h}$ prior to the addition of MtRV plant extract $\left(1.5 \mathrm{mg} \mathrm{mL}^{-1}\right)$. The total RNA isolation kit (A\&A Biotechnology, Gdynia, Poland) was used to isolate total RNA from cells treated with the plant extracts. The obtained RNA was transcribed into cDNA using TranScriba Kit (A\&A Biotechnology). Following this, the expression of four genes (Bax, Bcl-2, Cas-3, TP53) was measured by qRT-PCR using TaqMan ${ }^{\circledR}$ Real-Time PCR Master Mix (Life Technologies, Carlsbad, CA, USA) and Agilent 
Technologies Stratagene Mx300SP (Santa Clara, CA, USA) working on MxPro software. TaqMan probes (Life Technologies, CA, USA) were used to analyse genes and 18S RNA (Life Technologies) was included as a reference gene. The PCR was performed as follows: $95{ }^{\circ} \mathrm{C}$ for $10 \mathrm{~min}, 30$ cycles of $95{ }^{\circ} \mathrm{C}$ for $15 \mathrm{~s}$ and $60{ }^{\circ} \mathrm{C}$ for $60 \mathrm{~s}$.

\section{Western blot analysis}

Following treatment with MtRV extract for $24 \mathrm{~h}$, glioma cells were harvested, washed with ice-cold PBS (Thermo Fisher Scientific) and lysed in RIPA lysis buffer (Sigma-Aldrich, St. Louis, MO, USA) containing a protease-inhibitor cocktail tablet for $30 \mathrm{~min}$. The supernatant was collected after centrifuging at $18,000 \times g$ for $15 \mathrm{~min}$. Total protein was extracted and protein concentration was determined using a bicinchoninic acid assay kit (Thermo Fisher Scientific, CA, USA). For immunoblotting, $30 \mu \mathrm{g}$ protein from each sample was subjected to $4-20 \%$ ExpressPluS PAGE Gel (GenScript, Piscataway, New Jersey, USA) and separated proteins were transferred onto a PVDF membrane using eBlot Protein Transfer (GenScript, Piscataway, NJ, USA). The membrane was blocked with 5\% skimmed milk at room temperature for $1 \mathrm{~h}$ and then incubated with the primary antibodies against caspase-3, Bcl-2, Bax, p53 (Abcam, Cambridge, MA, USA) and GAPDH (SantaCruz Biotechnology, Santa Cruz, CA, USA), respectively, at $4{ }^{\circ} \mathrm{C}$ overnight. After washing, the membrane was incubated with anti-rabbit or anti-mouse HRP-conjugated secondary antibody. GAPDH was used as an internal control to monitor equal protein loading and transfer of proteins from the gel to the membranes. Signals were detected using an enhanced ECL reagent, and BioRad Universal Hood II with Chemiluminescence System (BioRad, Hercules, California, USA). The results shown are representative of three independent experiments.

Apoptosis/necrosis and cell cycle detection by flow cytometry

In this study, apoptotic and necrotic cells content in grade IV glioma cells was detected using an annexin V-fluorescein isothiocyanate (FITC)/propidium iodide (PI) detection kit (ThermoFisher Scientific, CA, USA) according to the manufacturer's instructions. Briefly, cells were plated into 6-well culture dishes $\left(2 \times 10^{5}\right.$ cells/well $)$ for $24 \mathrm{~h}$ prior to the addition of MtRV extract from $M$. trifoliata plants $\left(1.5 \mathrm{mg} \mathrm{mL}^{-1}\right)$. Following 24-h incubation with the tested MtRV extract, the percentage of apoptotic/ necrotic cells was determined by the annexin V-FITC/ PI assay. The content of glioma cells in different cell cycle phases was accessed using PI/RNase staining buffer (BD Biosciences, San Jose, CA). Cells were seeded as mentioned above and treated of MtRV extract. After $24 \mathrm{~h}$ incubation, medium was discarded and cells were collected and fixed with $70 \%$ cold ethanol for at least $1 \mathrm{~h}$ in $-20^{\circ} \mathrm{C}$. In the next step cells were suspended in staining buffer. Cell analysis was performed using CytoFlex Flow Cytometer (Beckman Coulter).

Assessment of mitochondrial membrane potential $(\Delta \Psi \mathrm{m})$

Briefly, the grade IV glioma cells at a concentration of $1 \times 10^{5}$ cells $/ \mathrm{mL}$ were incubated in 6-well plates for $24 \mathrm{~h}$ at $37{ }^{\circ} \mathrm{C}$ with $5 \% \mathrm{CO}_{2}$ with MtRV extract at a concentration of $1.5 \mathrm{mg} \mathrm{mL}^{-1}$. JC-1 (5,5',6,6'-tetrachloro-1,1',3,3'-tetraethylbenzimidazolyl carbocyanine iodide, Sigma-Aldrich, St. Louis, MO, USA) was used to measure the change in mitochondrial membrane potential $(\Delta \Psi \mathrm{m})$. After trypsinization, the cells were incubated with JC- 1 at $37{ }^{\circ} \mathrm{C}$ and $5 \% \mathrm{CO}_{2}$ for $30 \mathrm{~min}$. JC-1 accumulation in the mitochondria is potential dependent and is indicated by a fluorescence emission shift from green to red, with mitochondrial depolarization indicated by a lower ratio of red to green. The resulting fluorescence was measured on a Fluoroskan Ascent plate reader (Thermo Fisher Scientific, CA, USA). Filter pairs of $530 \mathrm{~nm} / 590 \mathrm{~nm}$ and $485 \mathrm{~nm} / 538 \mathrm{~nm}$ were used (Cossarizza et al. 1993).

\section{Statistical analysis}

Data is presented as mean \pm standard deviation (SD). The normality of data was verified by the ShapiroWilk test. The Kruskal-Wallis test was used to identify differences between data. Differences with $p$ values less than 0.05 were regarded as statistically significant. STATISTICA 13.1 software (StatSoft, Krakow, Poland) was used for all calculations. 


\section{Results}

Identification and quantification of compounds in aerial parts (MtAPV) and roots (MtRV) extracts from in vitro plants and in the aerial parts (MtAPS) and roots (MtRS) extracts from in vivo (soilgrown) plants of $M$. trifoliata

The polyphenolic compounds and pentacyclic triterpenes present in plant extracts of $M$. trifoliata were identified by comparison of retention times, and UV absorption spectra with those of the of authentic standard compounds. In the aqueous methanolic MtAPV, MtRV, MtAPS and MtRS extracts were identified fifteen phenolic acids (chlorogenic acid, synapinic acid, ellagic acid, syringic acid, vanillic acid, $p$-coumaric acid, $o$-coumaric acid, ferulic acid, salicylic acid, t-3-hydroxycinnaminic acid, t-cinnaminic acid, neochlorogenic acid, gentisinic acid, caffeic acid, 1,3-dicaffeoylquinic acid), five flavonoids (rutin, luteolin, hesperetin, hesperidin and coumarin), and one triterpene pentacyclic (betulinic acid) (Table 1). Betulinic acid was accumulated in higher amounts in the root extracts $\left(5437.15 \mu \mathrm{g} \mathrm{g}^{-1}\right.$ DW in MtRV and $3938.96 \mu \mathrm{g} \mathrm{g}^{-1}$ DW in MtRS) than in the extracts from the aerial parts $\left(395.31 \mu \mathrm{g} \mathrm{g}^{-1}\right.$ DW in MtAPV and $390.00 \mu \mathrm{g} \mathrm{g}^{-1}$ DW in MtAPS). The results indicate that the aerial parts of the in vitro and in vivo (soil-grown) plants contained significantly different levels of phenolic acids and flavonoids than the roots (Table 1). In the MtAPV and MtAPS extracts, the polyphenolic fraction was $1121.35 \mu \mathrm{g} \mathrm{g}^{-1} \mathrm{DW}$ and $726.65 \mu \mathrm{g} \mathrm{g}^{-1} \mathrm{DW}$, respectively, with ellagic acid, chlorogenic acid and rutin as the main constituents. In turn, in MtRV and MtRS, the polyphenolic fraction was 1416.06 and $861.78 \mu \mathrm{g} \mathrm{g}^{-1}$ DW, respectively, with sinapinic acid, syringic acid and rutin as the major compounds (Table 1). Additionally, other minor compounds were detected in plant extracts: vanillic acid, $p$-coumaric acid, $o$ coumaric acid, ferulic acid, salicylic acid, t-3-hydroxycinnaminic acid, t-cinnaminic acid, neochlorogenic acid, gentisinic acid, caffeic acid, 1,3-dicaffeoylquinic acid, luteolin, hesperetin, hesperidin and coumarin. A typical chromatogram of the aqueous methanolic extract of the $M$. trifoliata plants (MtRV extract) is shown in Figs. 3 and 4. Due to the highest content of polyphenolic compounds and pentacyclic triterpenes contained in the MtRV extract, this extract was chosen for further biological studies.

Cytotoxic effect of MtRV, MtAPV, MtRS and MtAPS extracts on human grade IV glioma cells and normal human astrocytes

All tested extracts showed cytotoxic effects in a dosedependent manner. A higher cytotoxic effect was observed for the MtRV and $\operatorname{MtRS}\left(2 \mathrm{mg} \mathrm{mL}^{-1}\right)$ extracts than MtAPV and MtAPS $\left(3 \mathrm{mg} \mathrm{mL}^{-1}\right)$ but the MtRV extract had a much more potent effect on grade IV glioma cells with $\mathrm{IC}_{50} 1.5 \mathrm{mg} \mathrm{mL}^{-1}$ (Fig. 5a). This extract was chosen for further biological analysis. In addition, no cytotoxic effect was observed on normal human astrocytes (NHA) for any tested extract within the test range $\left(0-4 \mathrm{mg} \mathrm{mL}^{-1}\right)$ (Fig. 5b). The survival of these cells after treatment with all tested extracts ranged from 80 to $90 \%$.

Flow cytometry and cell cycle analysis on grade IV glioma cells co-treated with different concentrations of MtRV extract

For flow cytometry analysis, the human grade IV glioma cells were treated for $24 \mathrm{~h}$ with different concentrations of MtRV extract $(0.25,0.5,1$, $\left.1.5 \mathrm{mg} \mathrm{mL}^{-1}\right)$ or DMSO $(0.1-0.3 \%)$, for controls, and then stained with Annexin-V-FITC and PI. Our results showed an increase in the $\mathrm{G} 2 / \mathrm{M}$ phase $(p<0.05)$ associated with the MtRV (0.25-1.5 mg mL ${ }^{-1}$ ) extract during the $24 \mathrm{~h}$ treatment period. A significantly more human grade IV glioma cells in the G2/M phase after treatment with $1.5 \mathrm{mg} \mathrm{mL}^{-1} \mathrm{MtRV}$ extract was observed (Fig. 6a). The data indicates that inhibition of grade IV glioma cell growth mediated by MtRV extract is associated with G2/M phase cell cycle arrest. Representative results for the human grade IV glioma cells grade are shown in Fig. 6b. The percentage of apoptotic cells increased from $1 \%$ in control cells to $40 \%$ after treatment with MtRV. This effect showed that the percentage of apoptotic cells was dose-dependent. The most effective concentration $\left(1.5 \mathrm{mg} \mathrm{mL}^{-1}\right)$ was chosen to our further studies. 
Fig. 3 RP-HPLC profile of betulinic acid standard (a) and plant extract (b), $1=$ betulinic acid

Fig. 4 Typical HPLC chromatogram of Menyanthes trifoliata in vitro root extract. Numbers correspond to the compound numbers in Table 1

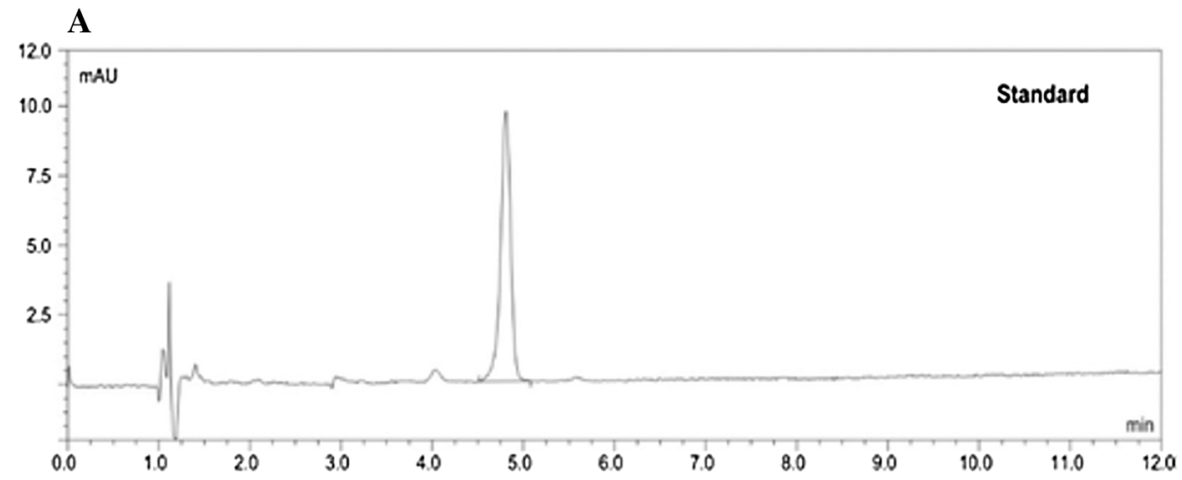

B
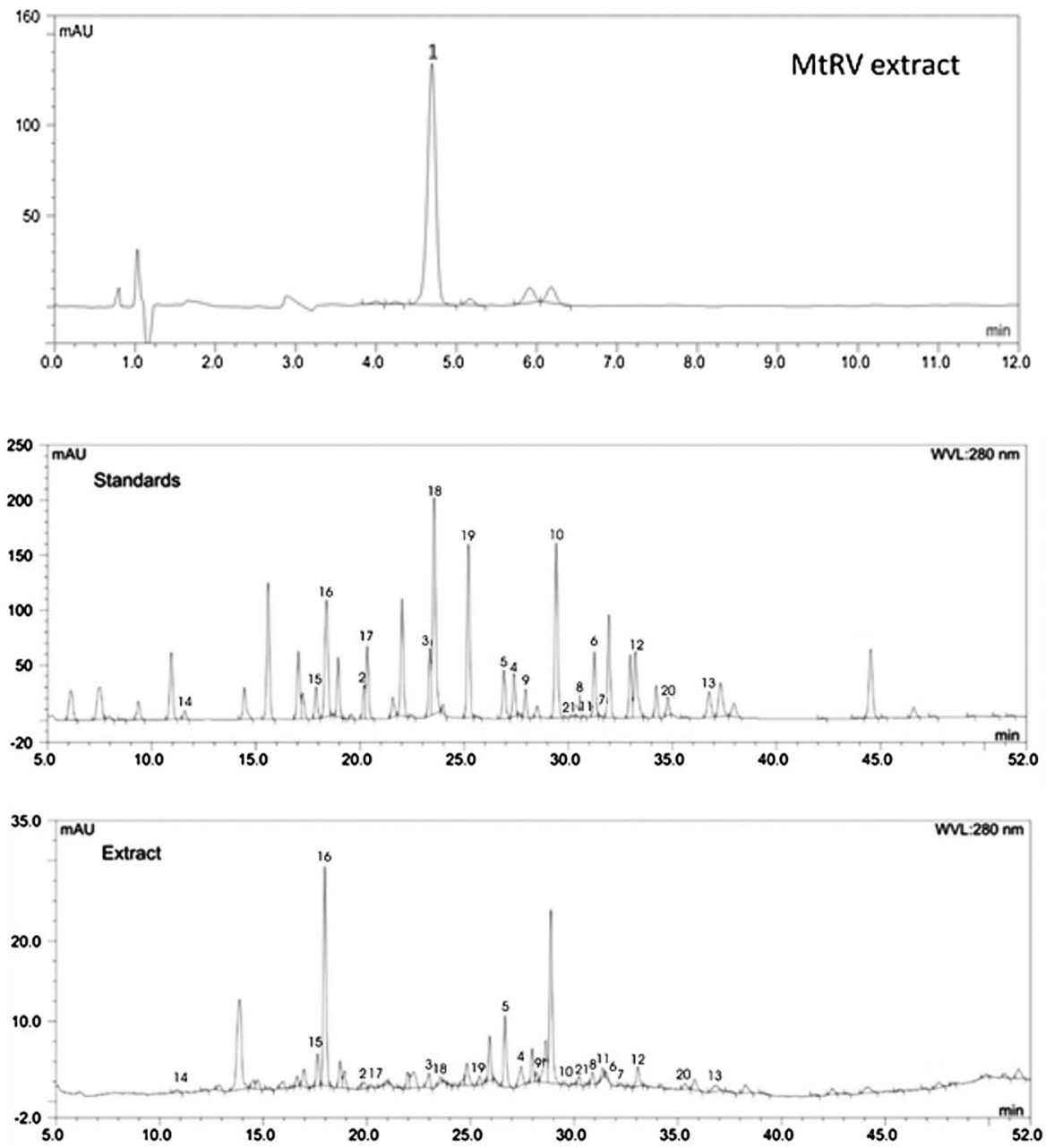
Fig. 5 a Cell viability of grade IV human glioma cells after treatment with MtAPV and MtRV of in vitro plant extracts and MtAPS and MtRS soil plant extracts of Menyanthes trifoliata in various concentrations (0-4 mg mL $\left.{ }^{-1}\right)$. b Cell viability of normal human astrocyte (NHA) cells after 24-h treatment with MtAPV and MtRV of in vitro plant extracts and MtAPS and MtRS soil plant extracts of Menyanthes trifoliata at various concentrations (0-4 $\mathrm{mg} \mathrm{mL}^{-1}$ ) The mean values $\pm \mathrm{SD}$ were calculated from three independent experiments. MtAPS—aerial parts from soil, MtRS—roots from soil, MtRV—roots in vitro, MtAPV—aerial parts in vitro. $p<0.05$, \#MtAPV versus MtAPS, *MtRV versus MtRS
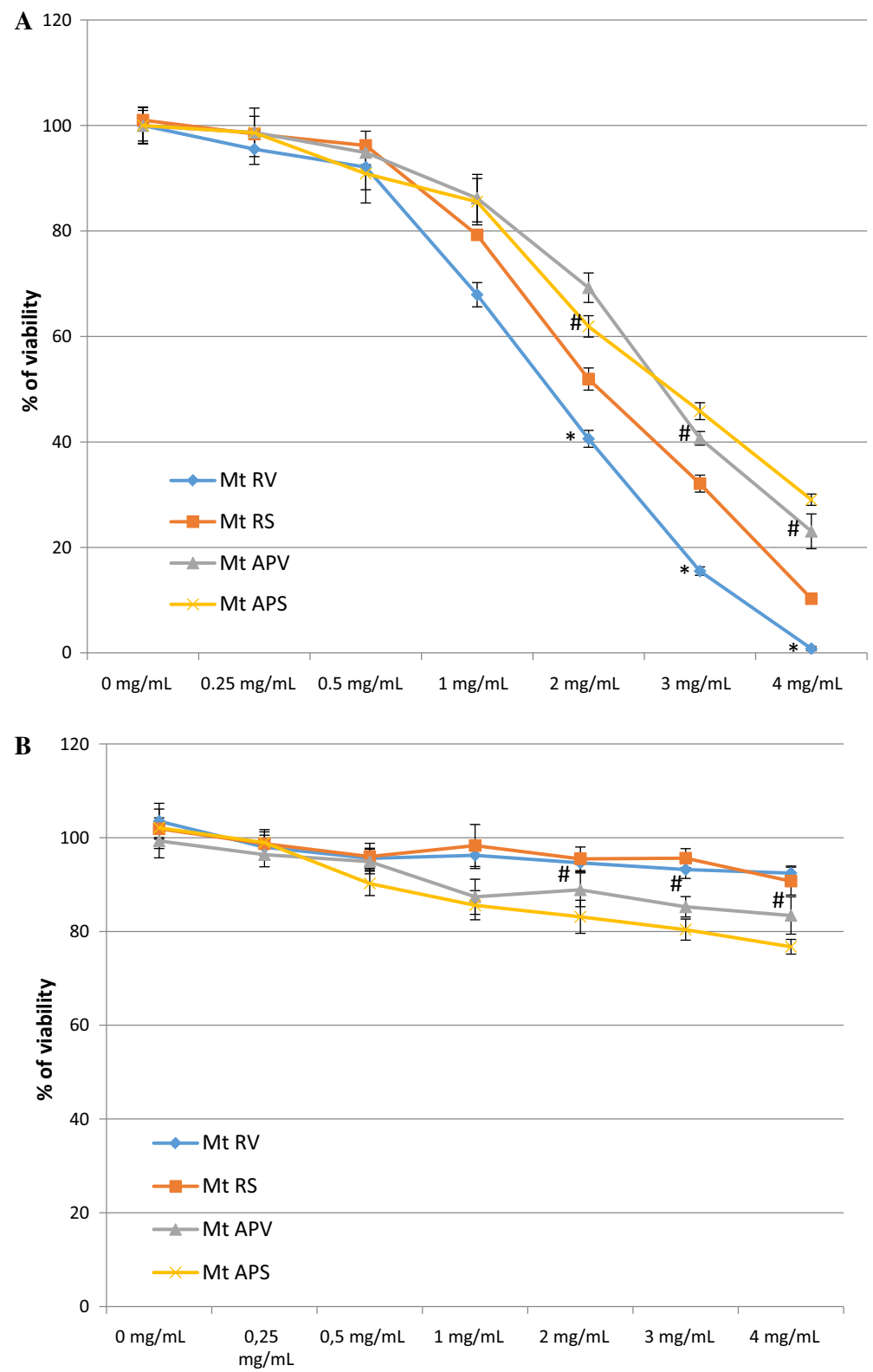

Expression of apoptosis-related genes in human grade IV glioma cells and loss of mitochondrial membrane potential after treatment with MtRV extract

To investigate the mechanism of apoptosis induction during 24-h incubation of human grade IV glioma cells with MtRV extract, qRT-PCR was used to evaluate the expression of several apoptosis genes, including Bcl-2, Bax, Cas-3 and TP53. Treatment of the human grade IV glioma cells with $1.5 \mathrm{mg} \mathrm{mL}^{-1}$
MtRV extract significantly decreased the mRNA level of Bcl-2 $(p<0.05)$ (Fig. 7a). In addition, the mRNA level of Bax, Cas-3 and TP53 was significantly increased after $24 \mathrm{~h}(p<0.05)$. The levels of apoptosis-related proteins were evaluated by Western blot analysis (Fig. 7c) and changes in their expression were confirmed (Bax, Cas-3 and p53). Additionally, after $24 \mathrm{~h}$, the MtRV extract was found to significantly reduce the level of $\Delta \Psi \mathrm{m}$ in human grade IV glioma cells by about 1.5 -fold in comparison to the control (Fig. 7b). This result confirms that MtRV extract 

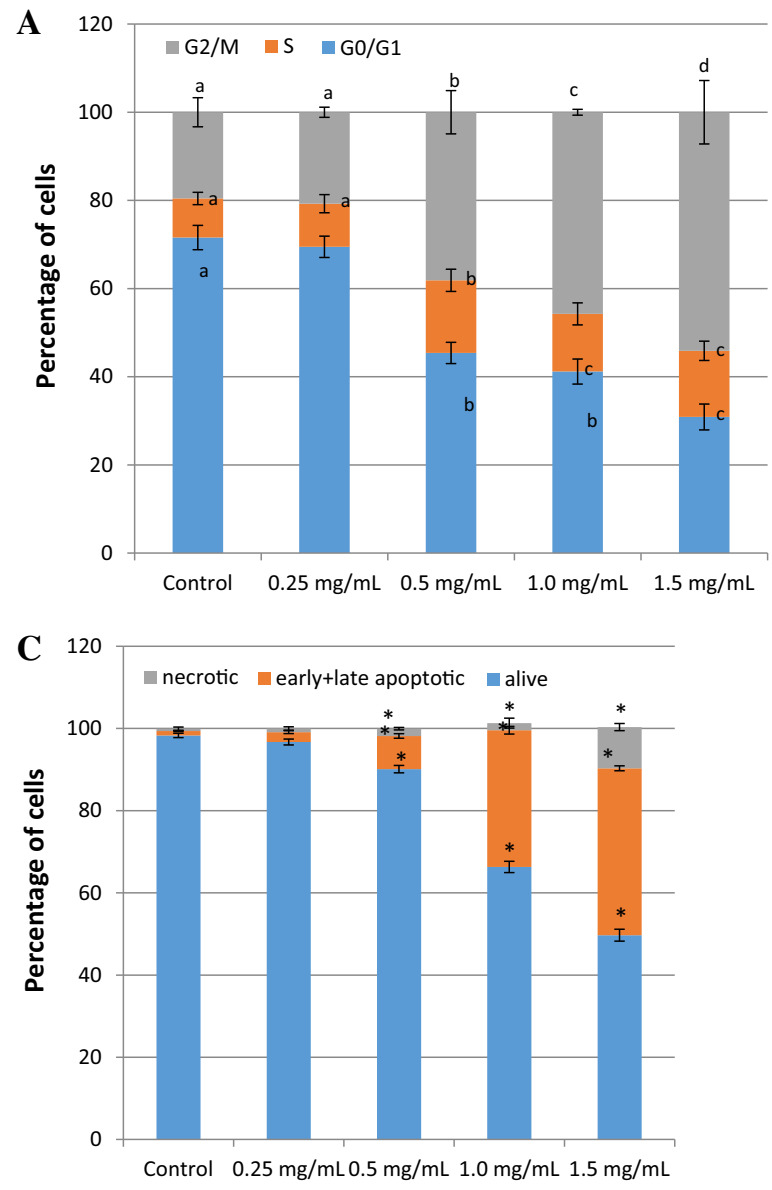

Fig. 6 a Cell cycle in human glioma cells on IV grade after treatment with MtRV extract of Menyanthes trifoliata at various concentrations $\left(0.25-1.5 \mathrm{mg} \mathrm{mL}^{-1}\right)$, different letter indicate significant differences in the mean values at $p<0.05$, b representative histograms of apoptosis induction in human grade IV glioma cells after treatment with in vitro root derived plant extract of Menyanthes trifoliata at various concentrations

induces apoptosis through the disruption of mitochondrial membrane potential. This reduction in mitochondrial membrane potential may well initiate the apoptotic cascade in the human grade IV glioma cells treated with MtRV extract of M. trifoliata plants.

\section{Discussion}

The plant kingdom is home to many valuable natural products, especially secondary metabolites, that perform a variety of functions in the plant, with some being involved in defence against biotic and abiotic stress or pathogens (Ahmed et al. 2017). The list of
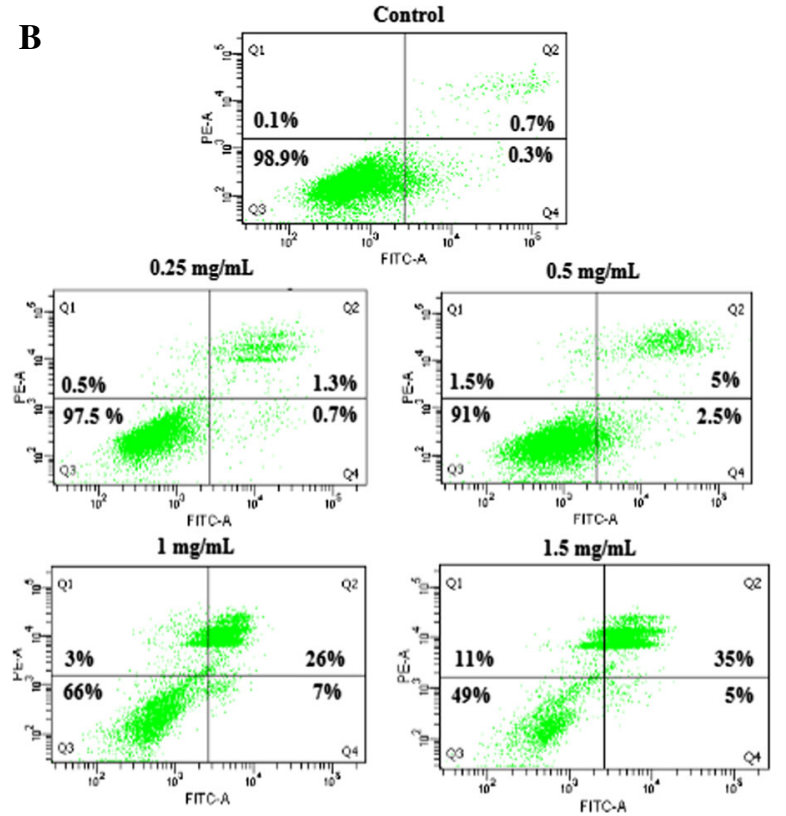

(0.25-1.5 mg mL $\left.{ }^{-1}\right)$, c diagram present percentage of early and late apoptosis, necrosis and alive cells after $24 \mathrm{~h}$ treatment with in vitro root derived plant extract of Menyanthes trifoliata at various concentrations $\left(0.25-1.5 \mathrm{mg} \mathrm{mL}^{-1}\right)$. The mean values $\pm \mathrm{SD}$ were calculated from three experiments. ${ }^{*} p<0.05$ Mt RV extract versus control

known secondary metabolites is extensive: Many exhibit pro-health properties and some of these are used to treat pathologies in humans (Skała et al. 2016). It has been demonstrated that the aqueous extract of $M$. trifoliata is able to induce a suppressive phenotype of dendritic cells that has a reduced capacity to induce Th1 and Th17 stimulation of allogeneic CD4(+) T cells (Jonsdottir et al. 2011). Other data indicate that polysaccharide-rich fractions from $M$. trifoliata play an important role as strong stimulators of immune cells, or as a potent suppressive and anti-inflammatory agents (Kuduk-Jaworska et al. 2004).

Various groups of chemical compounds in $M$. trifoliatat plants have been identified so far (Günter 

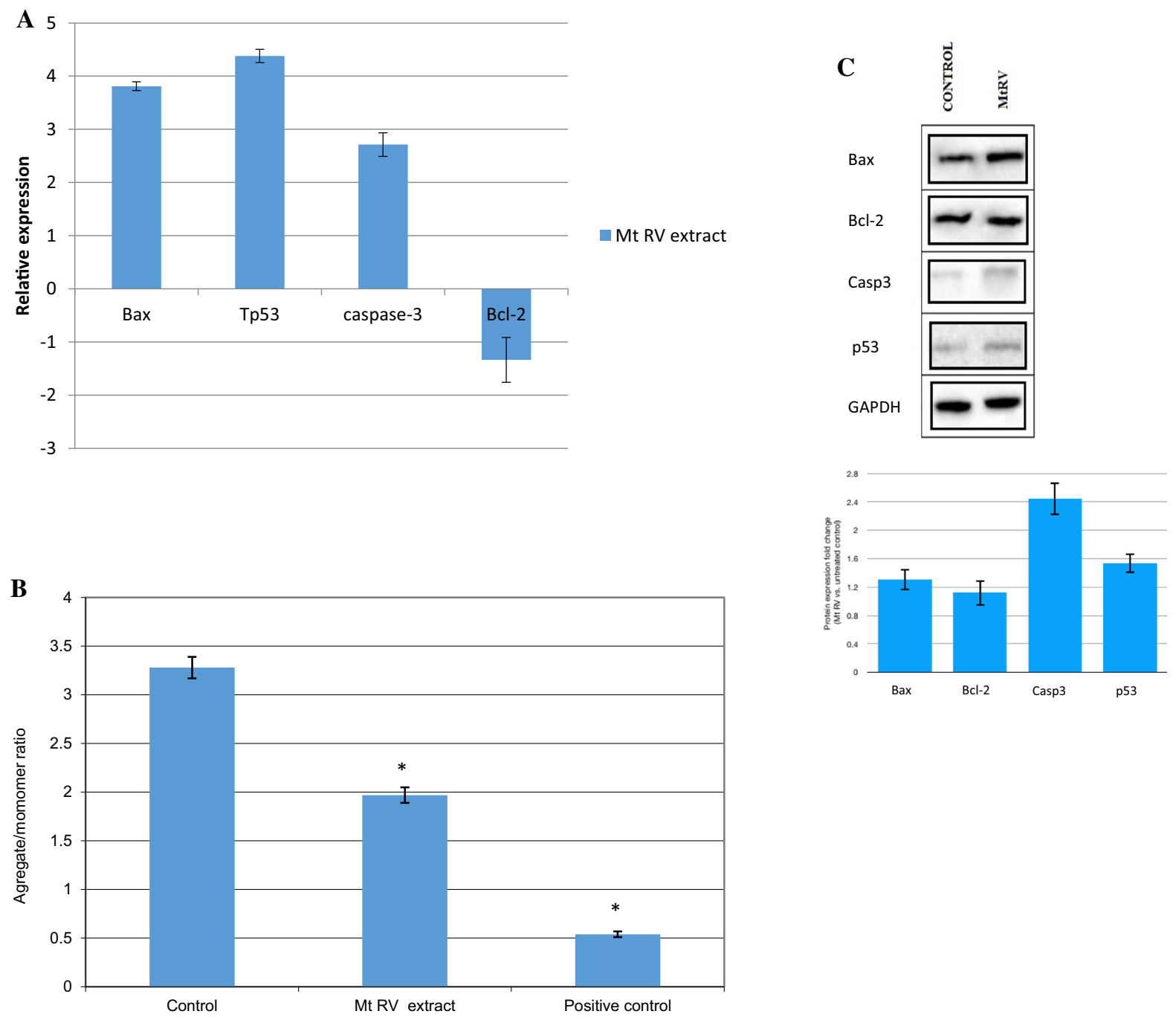

Fig. 7 a Expression of genes Bax, Bcl-2, Cas-3 and TP53 in human grade IV glioma cells after treatment with $1.5 \mathrm{mg} \mathrm{mL}^{-1}$ Mt RV in vitro plant extract of Menyathes trifoliata. The transcript level of each gene was normalized to the expression of a reference gene (18S RNA). Data is presented as fold change in human grade IV glioma cells after treatment of Menyanthes trifoliata extract versus untreated human grade IV glioma cells, in which expression levels of the genes were set as 1 . b Mitochondrial membrane potential in human grade IV glioma

and Krebs 1957; Battersby et al. 1968; Mel'chakova and Kharitonova 1976; Junior 1989; AdamczykRogozinska and Wysokińska 1998). Our findings indicate that total amount of phenolic compounds in the MtRV extract was $1416.06 \mu \mathrm{g} \mathrm{g}^{-1}$ dry weight, while the content in the MtAPV and MtAPS extracts was $1121.35 \mu \mathrm{g} \mathrm{g}^{-1} \mathrm{DW}$ and $726.65 \mu \mathrm{g} \mathrm{g}^{-1} \mathrm{DW}$, respectively, and $861.78 \mu \mathrm{g} \mathrm{g}^{-1}$ was present in MtRS. cells after treatment with $1.5 \mathrm{mg} \mathrm{mL}^{-1} \mathrm{Mt} \mathrm{RV}$ in vitro plant extract of Menyathes trifoliata. MMP is expressed as $530 \mathrm{~nm} /$ $590 \mathrm{~nm}$ to $485 \mathrm{~nm} / 538 \mathrm{~nm}$ (aggregates to monomer) fluorescence ratio, as quantified with a fluorescent plate reader after JC1 staining). The mean values $\pm \mathrm{SD}$ were calculated from three independent experiments. $p<0.05$ control versus MtRV and positive control. c Western blot analysis of MtRV extract on Bax, Bcl-2, Casp-3, p53 expression level

This indicates that $M$. trifoliata is a rich source of many valuable preventive and therapeutic compounds. Betulinic acid is present in the highest concentration in MtRV extract (5437.1 $\mathrm{g} \mathrm{g}^{-1} \mathrm{DW}$ ), which is 1.7times higher than the content in roots originating from MtRS (3122.1 $\left.\mu \mathrm{g} \mathrm{g}^{-1} \mathrm{DW}\right)$ and MtAPV and MtAPS (395.31 $\mu \mathrm{g} \mathrm{g}^{-1} \mathrm{DW}$ and $390.00 \mu \mathrm{g} \mathrm{g}^{-1} \mathrm{DW}$, respectively). For this reason, root extract from in vitro plants 
was used for further research in this work. As betulinic acid is known to exhibit anti-tumor properties against various types of cancer cells (Chintharlapalli et al. 2007; Fulda 2008; Reiner et al. 2013), the strong anticancer activity of MtRV extract may be due to its high content of betulinic acid. An important novel aspect of this study is that it is the first paper to compare the contents of biologically-active polyphenolic compounds in different parts of plants derived from in vitro and in vivo (soil-grown) cultures. There is very little data available on the cultivation and regeneration of $M$. trifoliata in vitro, and the study describes the establishment of $M$. trifoliata in vitro cultures and vegetative plant material propagation by apical meristem, which can represent an alternative to organogenesis. A previous study by Adamczyk-Rogozińska and Wysokińska (1998) found that the composition of the culture media, subculture number and the type and concentration of the cytokinin used have a great influence on the shoot multiplication rate of $M$. trifoliata during organogenesis from callus tissue. In our study, application of rooting medium and culture conditions gave very good results, allowing for intensive growth, rooting and development of in vitro plants for further analysis.

The MTT test demonstrated that $M$. trifoliata extracts had a cytotoxic effect against grade IV glioma cells. The best results were observed for MtRV extract $\left(\mathrm{IC}_{50}=1.5 \mathrm{mg} \mathrm{mL}^{-1}\right)$ which had the strongest influence on grade IV glioma cells. Additionally, our findings found that none of the tested extracts had a cytotoxic effect against normal human astrocytes (NHA) within the test range $\left(0-4 \mathrm{mg} \mathrm{mL}^{-1}\right)$. The survival for all extracts was between 80 and $90 \%$. The MtRV extract was able to inhibit cell growth, arresting cell cycle inthe $\mathrm{G} 2 / \mathrm{M}$ phase and finally inducing apoptosis in human glioma cells. The chosen MtRV extract induced apoptosis in a dose-dependent manner and the greatest cytotoxic effect was achieved at a concentration of $1.5 \mathrm{mg} \mathrm{mL}^{-1}$. A body of evidence acquired from other studies indicates that the plant extract, its fraction or isolated individual compounds induces G2/M phase arrest and apoptosis in a wide range of cancer cells (Yang et al. 2010; Yan et al. 2011; Kong et al. 2014). Many studies have examined the antitumor activity of betulinic acid (BA) (Fulda 2008; Ali-Seyed et al. 2016). One characteristic property of BA is its ability to induce the mitochondrial pathway of apoptosis in various cancer cells.
Betulinic acid also exhibits the ability to regulate the expression of Bcl-2 family proteins (Kumar et al. 2018). This process, known as programmed cell death, plays a crucial role in the development and maintenance of homeostasis in organisms (Henson and Hume 2006). The intrinsic (mitochondrial) pathway of apoptosis is based on the activity of the Bcl-2 family of proteins, and depends on the interaction between proapoptotic and antiapoptotic molecules; this converges on Bax/Bak activation, which controls mitochondrial outer membrane permeability (MOMP).

Our results indicate that treatment of cancer cells with plant extracts results in changes in the expression pattern of apoptosis-related genes. Incubation of the cancer cells in the presence of $1.5 \mathrm{mg} \mathrm{mL}^{-1} \mathrm{MtRV}$ extract for $24 \mathrm{~h}$ simultaneously increased the expression of the Bax proapoptotic gene and decreased that of the antiapoptotic $B c l-2$ gene. In addition, the TP53 and Casp-3 genes were found to be up-regulated in glioma cells after exposure to this extract; these proteins play an important role in tumor suppression, cell cycle arrest and the execution-phase of cell apoptosis (Delbridge et al. 2012; Li et al. 2012; Guo et al. 2014). Furthermore, our results also reveal a reduction in mitochondrial membrane potential, which may confirm the presence of an apoptotic cascade in grade IV glioma cells treated with MtRV extract. Based on our findings, indicating changes in the expression of apoptosis-related genes, the observed loss of mitochondrial membrane potential and apoptosis can be attributed to the influence of the higher concentrations of BA present in the MtRV extract, as noted by other authors (Xu et al. 2014; Shankar et al. 2017). Fulda et al. (1998) describe betulinic acid as a cytotoxic agent which induces apoptosis by a directly reducing the transmembrane potential of mitochondria. Mitochondria undergoing permeability transition induced by BA mediate the cleavage of caspase- 3 and caspase-8. It was also demonstrated that soluble factors such as cytochrome c or apoptosis-inducing factor released from BA-treated mitochondria are sufficient to initiate the cleavage of caspases and nuclear fragmentation. Previous studies also indicate that BA-treated cancer cells (glioma, melanoma, neuroblastoma) demonstrated upregulation of the pro-apoptotic Bax protein (Fulda et al. 1997; Wick et al. 1999; Selzer et al. 2000), indicating that plantderived products rich in BA could be potent agents in the fight against cancer cells. 
It is interesting to note that the highest content of BA was detected in roots derived from in vitro plants, indicating that this model merits further studies. Additionally, we predict that other compounds contained in the MtRV extract, such as syringic acid, sinapinic acid, ellagic acid, chlorogenic acid and rutin, may play an auxiliary role in the fight against cancer cells acting synergistically. Karthik et al. (2014) evaluated the anticancer activity of syringic acid (SA) in lung carcinoma A549 cell line. They confirmed that there was a significant increase in the percentage of apoptotic cells in the population of SA treated cells. Abaza et al. (2013) found SA to have antimitogenic and chemo-sensitizing activities against human colorectal cancer, thus altering the cell cycle (S/G2-M or G1/G2-M phases) and inducing apoptosis. Our analysis found SA to also be present in the roots of in vitro cultured $M$. trifoliata plants $\left(113.80 \mu \mathrm{g} \mathrm{g}^{-1}\right.$ DW).

Zhao et al. (2013) examined the influence of ellagic acid (EA) on the inhibition of pancreatic cancer growth in Balb $\mathrm{C}$ nude mice. It was demonstrated that treatment of PANC-1 xenografted mice with EA resulted in significant inhibition in tumor growth. This phenomenon was associated with suppression of cell proliferation, caspase- 3 activation and induction of PARP cleavage. Ellagic acid proved to be effective in inhibition of Bcl-2, cyclin D1, CDK2 and CDK6. This compound also induced the expression of Bax in tumor cells compared to untreated control ones. In another work, the same authors present EA as inducing cytotoxic effects and inhibiting the growth of human bladder cancer cells as a result of cell cycle arrest at the G0/G1 phase, accompanied by apoptotic cell death. Additionally, EA was found to cause the induction of apoptosis through caspase-, ROS- and intrinsic pathways and Bax expression (Ho et al. 2014). EA is also known to demonstrate broad anti-cancer activities, with previous studies reporting it to have potential value against breast cancer (Wang et al. 2012; Chen et al. 2015), prostate cancer (Pitchakarn et al. 2013; Vicinanza et al. 2013), bladder cancer (Ceci et al., 2016) and human osteogenic sarcoma (Han et al. 2006). In the present study, EA was found to be present at a concentration of $518.11 \mu \mathrm{g} \mathrm{g}^{-1} \mathrm{DW}$ in the MtRV extract, which may reinforce the anti-tumor activity of BA.

Also, the rutin and chlorogenic acid present in MtRV extract, in the current study (257.90 $\mu \mathrm{g} \mathrm{g}^{-1}$ and
177.34 dry weight, respectively), may exhibit antitumor properties similar to those described for other phenolic compounds (Chen et al. 2013; Yan et al. 2015; Zhang et al. 2015a, b; ben Sghaier et al. 2016; Gouthamchandra et al. 2017). Many studies indicate that phenolic compounds may play an important role in the prevention and treatment of cancer, and that natural, plant-derived compounds, do not typically demonstrate side effects, which is extremely important in cancer therapy.

\section{Conclusions}

The present study is the first to demonstrate the anticancer properties of root extract of $M$. trifoliata plants derived from in vitro against grade IV glioma cells. Our findings demonstrate that polyphenolic compounds (e.g. ellagic acid, hydroxybenzoic acid, syringic acid, sinapinic acid, chlorogenic acid, ferulic acid or rutin) and terpenoids (betulinic acid) present in this extract can exert a synergistic effect and induce apoptosis by G2/M phase cell cycle arrest, change the protein expression level of Bax, Bcl-2, Cas-3 and p53 and decreased mitochondrial membrane potential in grade IV glioma cells. Our further research will focus on demonstrating the other properties of this plant extract and its potential application in practice.

\section{Compliance with ethical standards}

Conflict of interest Authors declare that they have no conflict of interest.

Ethics approval The University of Lodz granted Ethical approval to carry out the study within its facilities (Ethical Application Ref: RNN/194/12/KE).

Open Access This article is distributed under the terms of the Creative Commons Attribution 4.0 International License (http:// creativecommons.org/licenses/by/4.0/), which permits unrestricted use, distribution, and reproduction in any medium, provided you give appropriate credit to the original author(s) and the source, provide a link to the Creative Commons license, and indicate if changes were made.

\section{References}

Abaza MS, Al-Attiyah R, Bhardwaj R, Abbadi G, Koyippally M, Afzal M (2013) Syringic acid from Tamarix aucheriana possesses antimitogenic and chemo-sensitizing activities in 
human colorectal cancer cells. Pharm Biol 51:1110-1124. https://doi.org/10.3109/13880209.2013.781194

Adamczyk-Rogozinska U, Wysokińska H (1998) Organ and plantlet regeneration of Menyanthes trifoliata through tissue culture. Acta Soc Bot Pol 67:161-166

Ahire V, Kumar A, Mishra KP, Kulkarni G (2017) Ellagic acid enhances apoptotic sensitivity of breast cancer cells to $\gamma$ radiation. Nutr Cancer 69:904-910. https://doi.org/10. 1080/01635581.2017.1339811

Ahmed E, Arshad M, Zakriyya Khan M, Shoaib Amjad H, Mehreen Sadaf H, Riaz I, Sabir S, Ahmad N, Sabaoon MA (2017) Secondary metabolites and their multidimensional prospective in plant life. J Pharmacogn Phytochem JPP 205:205-214

Ali-Seyed M, Jantan I, Vijayaraghavan K, Bukhari SNA (2016) Betulinic acid: recent advances in chemical modifications, effective delivery, and molecular mechanisms of a promising anticancer therapy. Chem Biol Drug Des 87:517-536

Battersby AR, Burnett AR, Knowles GD, Parsons PG (1968) Seco-cyclopentane glucosides from Menyanthes trifoliata: foliamenthin, dihydrofoliamenthin, and menthiafolin. Chem Commun 21:1277-1280

Ben Sghaier M, Pagano A, Mousslim M, Ammari Y, Kovacic H, Luis J (2016) Rutin inhibits proliferation, attenuates superoxide production and decreases adhesion and migration of human cancerous cells. Biomed Pharmacother 84:1972-1978. https://doi.org/10.1016/j.biopha.2016.11. 001

Ceci C, Tentori L, Atzori MG, Lacal PM, Bonanno E, Scimeca M, Cicconi R, Mattei M, de Martino MG, Vespasiani G, Miano R, Graziani G (2016) Ellagic acid inhibits bladder cancer invasiveness and in vivo tumor growth. Nutrients $8: 774$

Chen H, Miao Q, Geng M, Liu J, Huy Tiaan L, Pan J, Yang Y (2013) Anti-tumor effect of rutin on human neuroblastoma cell lines through inducing G2/M cell cycle arrest and promoting apoptosis. Sci World J 2013:269165. https://doi. org/10.1155/2013/269165

Chen HS, Bai MH, Zhang T, Li GD, Liu M (2015) Ellagic acid induces cell cycle arrest and apoptosis through TGF- $\beta$ / Smad3 signaling pathway in human breast cancer MCF-7 cells. Int J Oncol 46:1730-1738. https://doi.org/10.3892/ ijo.2015.2870

Chintharlapalli S, Papineni S, Ramaiah SK, Safe S (2007) Betulinic acid inhibits prostate cancer growth through inhibition of specificity protein transcription factors. Cancer Res 67:2816-2823. https://doi.org/10.1158/0008-5472. CAN-06-3735

Cossarizza A, Baccaranicontri M, Kalashnikova G, Franceschi C (1993) A new method for the cytofluorometric analysis of mitochondrial membrane potential using the J-aggregate forming lipophilic cation 5,5',6,6'-tetrachloro-1,1',3,3'-tetraethylbenzim idazolcarbocyanine iodide (JC-1). Biochem Biophys Res Commun. https://doi.org/10.1006/bbrc. 1993.2438

Davis ME (2016) Glioblastoma: overview of disease and treatment. Clin J Oncol Nurs 20:1-8. https://doi.org/10. 1188/16.CJON.S1.2-8

Deka S, Gorai S, Manna D, Trivedi V (2017) Evidence of PKC binding and translocation to explain the anticancer mechanism of chlorogenic acid in breast cancer cells. Curr Mol Med 17:79-89. https://doi.org/10.2174/ 1566524017666170209160619

Delbridge ARD, Valente LJ, Strasser A (2012) The role of the apoptotic machinery in tumor suppression. Cold Spring Harb Perspect, Biol, p 4

Einbond LS, Soffritti M, Esposti DD, Park T, Cruz E, Su T, Wu HA, Wang X, Zhang YJ, Ham J, Goldberg IJ, Kronenberg F, Vladimirova A (2009) Actein activates stress- and statinassociated responses and is bioavailable in Sprague-Dawley rats. Fundam Clin Pharmacol 23:311-321. https://doi. org/10.1111/j.1472-8206.2009.00673.x

Escandell JM, Kaler P, Recio MC, Sasazuki T, Shirasawa S, Augenlicht L, Rios JL, Klampfer L (2008) Activated kRas protects colon cancer cells from cucurbitacin-induced apoptosis: the role of p53 and p21. Biochem Pharmacol 76:198-207. https://doi.org/10.1016/j.bcp.2008.05.004

Fulda S (2008) Betulinic acid for cancer treatment and prevention. Int J Mol Sci 9:1096-1107

Fulda S, Friesen C, Los M, Scaffidi C, Mier W, Benedict M, Nunez G, Krammer PH, Peter ME, Debatin KM (1997) Betulinic acid triggers CD95 (APO-1/Fas)- and p53independent apoptosis via activation of caspases in neuroectodermal tumors. Cancer Res 57:4956-4964

Fulda S, Scaffidi G, Susin SA, Krammer PH, Kroemer G, Peter ME, Debatin KM (1998) Activation of mitochondria and release of mitochondrial apoptogenic factors by betulinic acid. J Biol Chem 273:33942-33948. https://doi.org/10. 1074/jbc.273.51.33942

Gouthamchandra K, Sudeep HV, Venkatesh BJ, Shyam Prasad K (2017) Chlorogenic acid complex (CGA7), standardized extract from green coffee beans exerts anticancer effects against cultured human colon cancer HCT-116 cells. Food Sci Hum Wellness 6:147-153

Guimarães CM, Gião MS, Martinez SS, Pintado AI, Pintado ME, Bento LS, Malcata FX (2007) Antioxidant activity of sugar molasses, including protective effect against DNA oxidative damage. J Food Sci 72:39-43. https://doi.org/10. 1111/j.1750-3841.2006.00231.x

Günter K, Krebs JM (1957) Flavonglykoside in Menyanthes trifoliata L. (Bitterklee). Naturwissenschaften 44:422-423

Guo XX, Li Y, Sun C, Jiang D, Lin YJ, Jin FX, Lee SK, Jin YH (2014) p53-dependent Fas expression is critical for Ginsenoside $\mathrm{Rh} 2$ triggered caspase- 8 activation in HeLa cells. Protein Cell 5:224-234. https://doi.org/10.1007/s13238014-0027-2

Han DH, Lee MJ, Kim JH (2006) Antioxidant and apoptosisinducing activities of ellagic acid. Anticancer Res 26:3601-3606

Henson PM, Hume DA (2006) Apoptotic cell removal in development and tissue homeostasis. Trends Immunol 27:244-250

Ho CC, Huang AC, Yu CS, Lien JC, Wu SH, Huang YP, Huang HY, Kuo JH, Liao WY, Yang JS, Chen PY, Chung JG (2014) Ellagic acid induces apoptosis in TSGH8301 human bladder cancer cells through the endoplasmic reticulum stress- and mitochondria-dependent signaling pathways. Environ Toxicol 29:1262-1274. https://doi.org/10.1002/ tox. 21857 
Huang C, Tunon H, Bohlin L (1995) Anti-inflammatory compounds isolated from Menyanthes trifoliata L. Yao Xue Xue Bao 30:621-626

Huang M, Lu JJ, Huang MQ, Bao JL, Chen XP, Wang YT (2012) Terpenoids: natural products for cancer therapy. Expert Opin Investig Drugs 21:1801-1818. https://doi.org/ 10.1517/13543784.2012.727395

Janeczko Z, Sendra J, Kmieć K, Brieskorn CH (1990) A triterpenoid glycoside from Menyanthes trifoliata. Phytochemistry 29:3885-3887. https://doi.org/10.1016/00319422(90)85352-G

Jonsdottir G, Omarsdottir S, Vikingsson A, Hardardottir I, Freysdottir J (2011) Aqueous extracts from Menyanthes trifoliate and Achillea millefolium affect maturation of human dendritic cells and their activation of allogeneic CD4+ T cells in vitro. J Ethnopharmacol 136:88-93. https://doi.org/10.1016/j.jep.2011.04.006

Junior P (1989) Further investigations regarding distribution and structure of the bitter principles from Menyanthes trifoliata. Planta Med 55:83-87. https://doi.org/10.1055/s-2006961835

Karthik G, Vijayakumar A, Natarajapillai S (2014) Preliminary study on salubrious effect of syringic acid on apoptosis in human lung carcinoma A549 cells and Insilico analysis through docking studies. Asian J Pharm Clin Res 7:46-49

Kim SH, Ryu HG, Lee J, Shin J, Harikishore A, Jung HY, Seul Kim Y, Lyu HN, Oh E, Baek NI, Choi KY, Sup Yoon H, Kim KT (2015) Ursolic acid exerts anti-cancer activity by suppressing vaccinia-related kinase 1-mediated damage repair in lung cancer cells. Sci Rep 5:14570. https://doi. org/10.1038/srep14570

Kong Y, Chen J, Zhou Z, Xia H, Qiu MH, Chen C (2014) Cucurbitacin e induces cell cycle G2/M phase arrest and apoptosis in triple negative breast cancer. PLoS ONE 9:e103760. https://doi.org/10.1371/journal.pone.0103760

Kuduk-Jaworska J, Szpunar J, Gasiorowski K, Brokos B (2004) Immunomodulating polysaccharide fractions of Menyanthes trifoliata L. Zeitschrift fur Naturforsch Sect C J Biosci 59:485-493

Kumar P, Bhadauria AS, Singh AK, Saha S (2018) Betulinic acid as apoptosis activator: molecular mechanisms, mathematical modeling and chemical modifications. Life Sci 209:24-33. https://doi.org/10.1016/j.lfs.2018.07.056

Li T, Kon N, Jiang L, TanM Ludwig T, Zhao Y, Baer R, Gu W (2012) Tumor suppression in the absence of p53-mediated cell-cycle arrest, apoptosis, and senescence. Cell 149:1269-1283. https://doi.org/10.1016/j.cell.2012.04.026

Mady FM, Shaker MA (2017) Enhanced anticancer activity and oral bioavailability of ellagic acid through encapsulation in biodegradable polymeric nanoparticles. Int $\mathbf{J}$ Nanomed 12:7405-7417. https://doi.org/10.2147/IJN.S147740

Mel'chakova TN, Kharitonova NP (1976) Amounts of rutin and hyperoside in Menyanthes trifoliata. Chem Nat Compd 12:97

Pai SR, Nimbalkar MS, Pawar NV, Dixit GB (2011) Optimization of extraction techniques and quantification of betulinic acid (BA) by RP-HPLC method from Ancistrocladus heyneanus wall. Ex Grah. Ind Crops Prod 34:1458-1464. https://doi.org/10.1016/j.indcrop.2011.05. 006
Patočka J (2003) Biologically active pentacyclic triterpenes and their current medicine signification. J Appl Biomed 1:7-12

Pitchakarn P, Chewonarin T, Ogawa K, Suzuki S, Asamoto M, Takahashi S, Shirai T, Limtrakul P (2013) Ellagic acid inhibits migration and invasion by prostate cancer cell lines. Asian Pac J Cancer Prev 14:2859-2863. https://doi. org/10.7314/APJCP.2013.14.5.2859

Qi H, Wei L, Han Y, Zhang Q, Lau AS, Rong J (2010) Proteomic characterization of the cellular response to chemopreventive triterpenoid astragaloside IV in human hepatocellular carcinoma cell line HepG2. Int J Oncol 36:725-735

Reiner T, Parrondo R, de las Pozas A, Palenzuela D, PerezStable C (2013) Betulinic acid selectively increases protein degradation and enhances prostate cancer-specific apoptosis: possible role for inhibition of deubiquitinase activity. PLoS ONE 8:e56234. https://doi.org/10.1371/journal. pone. 0056234

Sadeghi Ekbatan S, Li XQ, Ghorbani M, Azadi B, Kubow S (2018) Chlorogenic acid and its microbial metabolites exert anti-proliferative effects, S-phase cell-cycle arrest and apoptosis in human colon cancer caco- 2 cells. Int J Mol Sci 19:723. https://doi.org/10.3390/ijms19030723

Sandjo LP, Kuete V (2013) Triterpenes and steroids from the medicinal plants of Africa. In: Kuete V (ed) Medicinal plant research in Africa: pharmacology and chemistry. Elsevier, pp 135-202

Schenk RV, Hildebrandt AC (1972) Medium and techniques for induction and growth of monocotyledonous and dicotyledonous plant cell cultures. Can J Bot 50:199-204

Selzer E, Pimentel E, Wacheck V, Schlegel W, Pehamberger H, Jansen B, Kodym R (2000) Effects of betulinic acid alone and in combination with irradiation in human melanoma cells. J Invest Dermatol 114:935-940. https://doi.org/10. 1046/j.1523-1747.2000.00972.x

Shankar E, Zhang A, Franco D, Gupta S (2017) Betulinic acidmediated apoptosis in human prostate cancer cells involves p53 and nuclear factor-kappa B (NF- $\mathrm{B})$ pathways. Molecules 22:264

Sitarek P, Skała E, Toma M, Wielanek M, Szemraj J, Nieborowska-Skorska M, Kolasa M, Skorski T, Wysokińska H, Śliwiński T (2016a) A preliminary study of apoptosis induction in glioma cells via alteration of the Bax/Bcl-2p53 axis by transformed and non-transformed root extracts of Leonurus sibiricus L. Tumor Biol 37:8753-8764. https://doi.org/10.1007/s13277-015-4714-2

Sitarek P, Skała E, Wysokińska H, Wielanek M, Szemraj J, Toma M (2016b) The effect of Leonurus sibiricus plant extracts on stimulating repair and protective activity against oxidative DNA damage in CHO cells and content of phenolic compounds. Oxid Med Cell Longev 2016:5738193. https://doi.org/10.1155/2016/5738193

Skała E, Sitarek P, Toma M, Szemraj J, Radek M, NieborowskaSkorska M, Skorski T, Wysokinska H, Sliwinski T (2016) Inhibition of human glioma cell proliferation by altered Bax/Bcl-2-p53 expression and apoptosis induction by Rhaponticum carthamoides extracts from transformed and normal roots. J Pharm Pharmacol 68:1454-1464

Stabursvik A (1953) Occurence of betulinic acid in Menyanthes trifoliata L. Acta chem Scand 7:446-447 
Tiwari R, Puthli A, Balakrishnan S, Sapra BK, Mishra KP (2014) Betulinic acid-induced cytotoxicity in human breast tumor cell lines MCF-7 and T47D and its modification by tocopherol. Cancer Invest 32:402-408. https://doi.org/10. 3109/07357907.2014.933234

Tunón H, Bohlin L, Öjteg G (1994) The effect of Menyanthes trifoliata L. on acute renal failure might be due to PAFinhibition. Phytomedicine 1:39-45. https://doi.org/10. 1016/S0944-7113(11)80021-8

Vicinanza R, Zhang Y, Henning SM, Heber D (2013) Pomegranate juice metabolites, ellagic acid and urolithin A, synergistically inhibit androgen-independent prostate cancer cell growth via distinct effects on cell cycle control and apoptosis. Evid Based Complement Altern Med 2013:247504. https://doi.org/10.1155/2013/247504

Wang N, Wang ZY, Mo SL, Loo TY, Wang DM, Luo HB, Yang DP, Chen YL, Shen JG, Chen JP (2012) Ellagic acid, a phenolic compound, exerts anti-angiogenesis effects via VEGFR-2 signaling pathway in breast cancer. Breast Cancer Res Treat 134:943-955. https://doi.org/10.1007/ s10549-012-1977-9

Wang X, Jia Y, Wang P, Liu Q, Zheng H (2017) Current status and future perspectives of sonodynamic therapy in glioma treatment. Ultrason Sonochem 37:592-599

Wick W, Grimmel C, Wagenknecht B, Dichgans J, Weller M (1999) Betulinic acid-induced apoptosis in glioma cells: a sequential requirement for new protein synthesis, formation of reactive oxygen species, and caspase processing. J Pharmacol Exp Ther 289:1306-1312

Xu T, Pang Q, Zhou D, Zhang A, Luo S, Wang Y, Yan X (2014) Proteomic investigation into betulinic acid-induced apoptosis of human cervical cancer HeLa cells. PLoS ONE 9:e105768. https://doi.org/10.1371/journal.pone.0105768
Yan H, Zhu Y, Liu B, Wu H, Li Y, Wu X, Zhou Q, Xu K (2011) Mitogen-activated protein kinase mediates the apoptosis of highly metastatic human non-small cell lung cancer cells induced by isothiocyanates. Br J Nutr 106:1779-1791. https://doi.org/10.1017/S0007114511002315

Yan Y, Li J, Han J, Hou N, Song Y, Dong L (2015) Chlorogenic acid enhances the effects of 5-fluorouracil in human hepatocellular carcinoma cells through the inhibition of extracellular signal-regulated kinases. Anticancer Drugs 26:540-546. https://doi.org/10.1097/CAD.0000000000 000218

Yang L, Chen Y, Ma Q, Fang J, He J, Cheng YQ, Wu QL (2010) Effect of betulinic acid on the regulation of Hiwi and cyclin B1 in human gastric adenocarcinoma AGS cells. Acta Pharmacol Sin 31:66-72. https://doi.org/10.1038/aps. 2009.177

Zhang J, Yao Z, Liang G, Chen X, Wu H, Jin L (2015a) Combination of lapatinib with chlorogenic acid inhibits breast cancer metastasis by suppressing macrophage M2 polarization. Zhejiang Da Xue Xue Bao Yi Xue Ban 44:493-499. https://doi.org/10.1002/rrr.3450110102

Zhang DM, Xu HG, Wang L, Li YJ, Sun PH, Wu XM, Wang GJ, Chen WM, Ye WC (2015b) Betulinic acid and its derivatives as potential antitumor agents. Med Res Rev 35:1127-1155. https://doi.org/10.1002/med

Zhao M, Tang SN, Marsh JL, Shankar S, Srivatava RK (2013) Ellagic acid inhibits human pancreatic cancer growth in Balb c nude mice. Cancer Lett 337:210-217. https://doi. org/10.1016/j.canlet.2013.05.009

Publisher's Note Springer Nature remains neutral with regard to jurisdictional claims in published maps and institutional affiliations. 